\title{
Rubella cataract and retinopathy
}

\author{
Ravi Bypareddy, Rohan Chawla, Shorya Vardhan Azad, Sudarshan Khokhar
}

Dr Rajendra Prasad Centre For Ophthalmic Sciences, All India Institute of Medical Sciences, New Delhi, India

\section{Correspondence to} Dr Ravi Bypareddy, raviaiims1@gmail.com

Accepted 26 May 2016

\section{DESCRIPTION}

A 10-year-old boy presented for evaluation of a squint and low vision in his left eye. He had undergone cataract surgery (lens aspiration and anterior vitrectomy) in the same eye at the age of 1 year. He also had sensorineural hearing loss. On examination, microphthalmos of the left eye was present along with exotropia with normal range of extraocular movements (figure 1). Best-corrected visual acuity in the right eye was $6 / 6$ and $6 / 60$ in the left eye. Anterior segment of the left eye revealed aphakia. Right eye anterior segment was unremarkable. Fundus examination of both eyes revealed classical 'salt and pepper'-like pigmentary retinal changes suggestive of rubella retinopathy (figure 2). Cardiovascular examination revealed asymptomatic

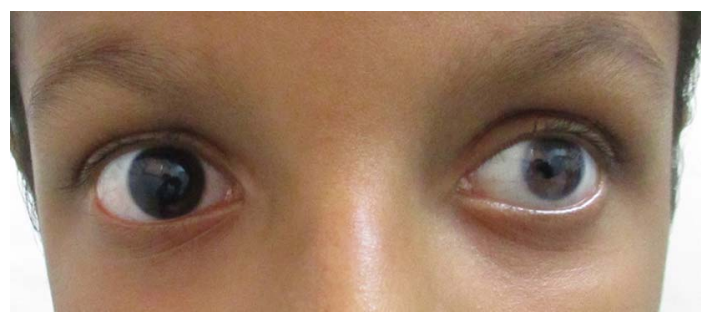

Figure 1 Left eye with evidence of micro-ophthalmia.

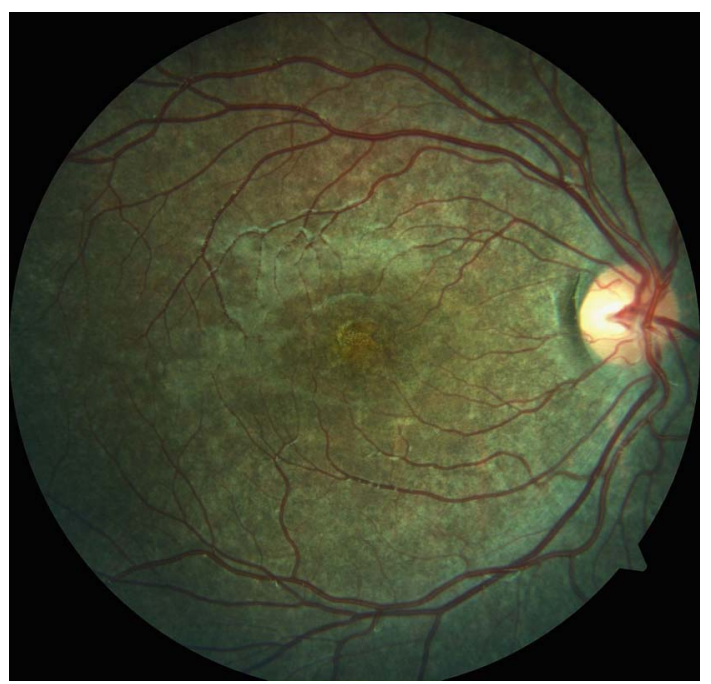

Figure 2 Fundus photo of the right eye showing characteristic 'salt and pepper' retinopathy. patent ductus arteriosus. All the above features contributed to the diagnosis of congenital rubella syndrome (CRS).

CRS is a catastrophic complication of rubella infection in pregnant women. ${ }^{1}$ The risk of fetal infection is greater in the first and third trimester. ${ }^{2}$ The common systemic manifestations associated with CRS are deafness, mental retardation, and cardiovascular and ocular defects. ${ }^{3}$ Eye findings such as cataract, microphthalmia and retinopathy are frequent findings, as in our patient. The patient was advised to wear contact lenses along with undergoing occlusion therapy to treat his amblyopia. Secondary intraocular lens implantation could also be considered as an option for later visual rehabilitation.

\section{Learning points}

- Congenital rubella syndrome is characterised by a triad of sensorineural hearing loss, eye abnormalities and congenital cardiac defects.

- Cataract, micro-ophthalmia and retinopathy are the ophthalmic manifestations common in this condition.
To cite: Bypareddy $R$, Chawla R, Azad SV, et al. BMJ Case Rep Published online: [please include Day Month Year] doi:10.1136/ bcr-2016-216112
Contributors RB was involved in the conception and design, acquisition of data, and analysis and interpretation of data; agreement to be accountable for the article and to ensure that al questions regarding the accuracy or integrity of the article are investigated and resolved. RC was involved in drafting the article and revising it critically for important intellectual content. SVA and SK was involved final approval of the version published.

Competing interests None declared.

Patient consent Obtained.

Provenance and peer review Not commissioned; externally peer reviewed.

\section{REFERENCES}

1 Reef SE, Plotkin S, Cordero JF, et al. Preparing for elimination of congenital Rubella syndrome (CRS): summary of a workshop on CRS elimination in the United States. Clin Infect Dis 2000;31:85-95.

2 Figueroa-Damián R, Ortiz-Ibarra FJ, Arredondo-García JL, et al. The outcome of pregnancies complicated by rubella, 1990-1997. Salud Publica Mex 1999;41:271-7.

3 Miller E, Cradock-Watson JE, Pollock TM. Consequences of confirmed maternal rubella at successive stages of pregnancy. Lancet 1982;2:781-4. 


\section{Images in...}

Copyright 2016 BMJ Publishing Group. All rights reserved. For permission to reuse any of this content visit http://group.bmj.com/group/rights-licensing/permissions.

BMJ Case Report Fellows may re-use this article for personal use and teaching without any further permission.

Become a Fellow of BMJ Case Reports today and you can:

- Submit as many cases as you like

- Enjoy fast sympathetic peer review and rapid publication of accepted articles

- Access all the published articles

- Re-use any of the published material for personal use and teaching without further permission

For information on Institutional Fellowships contact consortiasales@bmjgroup.com

Visit casereports.bmj.com for more articles like this and to become a Fellow 